\title{
NOVEL ANAK RASIAH KODEU BINER KARYA DADAN SUTISNA SEBAGAI BAHAN PEMBELAJARAN APRESIASI SASTRA DI SMP (Analisis Strukturalisme dan Etnopedagogik)
}

\author{
Euis Siti Fatimah \\ SMP Negeri 3 Langkaplancar \\ Pos-el: euis.sitifatimah@yahoo.com
}

\begin{abstract}
Abstrak
Tujuan penelitian ini adalah untuk mendeskripsikan unsur struktural dan etnopedagogik novel Rasiah Kodeu Biner sebagai alternatif bahan pengajaran apresiasi sastra. Metode yang digunakan dalam penelitian ini adalah metode deskriptif analisis, sedangkan teknik yang digunakan adalah teknik telaah pustaka, analisis data, dan teknik interpretasi. Hasil penelitian ditemukan tema novel tentang usaha sekelompok anak memecahkan rahasia surat yang menggunakan bilangan biner. Alur yang digunakan alur campuran. Jumlah tokoh 43 orang. Latar yang ditemukan dalam penelitian ini diantaranya latar tempat, waktu, dan sosial. Judul telah mewakili isi cerita. Pengarang menggunakan sudut pandang orang ketiga. Bahasa yang digunakan bahasa sehari-hari. Novel Rasiah Kodeu Biner memiliki banyak nilai etnopedagogik moral kemanusiaan. Novel ini bisa dijadikan alternatif bahan pembelajaran apresiasi sastra karena memenuhi kriteria pemilihan bahan ajar serta mengandung nilai moral kemanusian sesuai kepribadian siswa.
\end{abstract}

Kata kunci: struktural, etnopedagogik, novel, bahan pangajaran

$$
\begin{gathered}
\text { ANAK RASIAH KODEU BINER NOVEL } \\
\text { OF DADAN SUTISNA LITERARY WORKS AS LITERATURE APPRECIATION } \\
\text { TEACHING-LEARNING MATERIAL AT JUNIOR HIGH SCHOOL } \\
\text { (Structuralism and Ethnopedagogic Analysis) }
\end{gathered}
$$

\begin{abstract}
The purpose of this study is to describe the structural and ethnopedagogic elements of Rasiah Kodeu Biner novel as an alternative of literature appreciation teaching-learning material. The method used in this research is descriptive analysis method, while the techniques used are literature review techniques, data analysis, and interpretation techniques. The results of the study revealed that the novel theme is about the effort of group of children to solve the secret letter using binary numbers. The sequel used is mixed sequel. Numbers of characters are 43 people. The backgrounds found in this study include setting place, time, and social. The title has represented the story content. The author uses a third-person point of view. Language used is common language. Rasiah Kodeu Biner novel has many ethnopedagogic moral values of humanity. This novel can be used as an alternative material in teachinglearning literature appreciation, as it meets the criteria of the selection of teaching-learning materials and contains the moral values of humanity suitable with the students' personality.
\end{abstract}

Keywords: structural, ethnopedagogic, novel, teaching-learning materials 


\section{PENDAHULUAN}

Manusia diciptakan sebagai makhluk yang paling sempurna karena dianugerahi akal dan pikiran. Meskipun demikian perkembangan akal dan pikiran manusia tergantung pada individu masing-masing. Apakah individu tersebut memanfaatkan potensi yang dimilikinya atau tidak. Salah satu cara untuk meningkatkan kemampuan akal dan pikiran adalah dengan mencari berbagai informasi sebagai bekal pengetahuan untuk dirinya. Kebutuhan akan informasi seperti itu tidak hanya diperlukan oleh orang dewasa, tetapi juga oleh anak-anak. Informasi inilah yang kemudian dapat meningkatkan kemampuan kognisi, emosi, dan keterampilan anak dalam menghadapi kehidupannya.

Banyak cara yang bisa dilakukan untuk menambah informasi bagi anakanak, salah satunya membaca karya sastra. Hal ini sesuai dengan pendapat Nurgiantoro (dalam Kurniawan, 2009, hlm. 2) yang menyebutkan bahwa penyedian buku bacaan sastra kepada anakanak yang tepat sejak dini, sejak masih bernama anak, diyakini akan membantu literasi dan kemauan membaca anak pada perkembangan usia selanjutnya. Yang lebih penting lagi, dengan cerita, anak bisa mendapatkan nilai-nilai moral yang menunjang perkembangan budi pekertinya.

Lantas karya sastra yang seperti apa yang sesuai untuk anak-anak. Tentu hal ini harus menjadi pertimbangan para guru dan orang tua untuk mimilihkan karya sastra yang baik dan sesuai untuk anak-anak. Menurut Lukens (dalam Nurgiyantoro, 2010, hlm. 3) sastra anak sekurangkurangnya dapat menawarkan dua hal, yaitu kesenangan dan pemahaman. Sastra hadir untuk memberikan hiburan yang menyenangkan. Artinya, sastra harus menampilkan cerita yang menarik, dan mengajak pembaca memanjakan fantasinya. Selain itu, karya sastra harus bisa memberikan pemahaman yang lebih baik tentang kehidupan.
Sastra anak tentu harus mengacu kepada kehidupan cerita yang berkorelasi dengan dunia anak-anak dan bahasa yang digunakan sesuai dengan perkembangan intelektual dan emosional anak. Hal ini menunjukan bahwa batasan sastra hanyalah pada karyanya, sedangkan dimensi lain seperti pengarang dan pembaca tidak mutlak harus anak-anak (Kurniawan, 2009, hlm. 22).

Berdasarkan pembacanya, novel dalam sastra Sunda dibagi ke dalam tiga jenis, yaitu: 1) novel anak; 2) novel remaja; dan 3) novel dewasa (Sudaryat spk, 2007, hlm. 151). Kriteria novel anak di antaranya: 1) bahasa yang digunakan dalam novel adalah bahasa yang mudah dipahami oleh anak-anak, yaitu bahasa yang sesuai dengan tingkat perkembangan dan pemahaman anak; 2) pesan yang disampaikan berupa moral dan pendidikan yang disesuaikan dengan tingkat perkembangan dan pemahaman anak.

Pendidikan moral yang terdapat dalam novel anak berbahasa Sunda berasal dari nilai-nilai budaya lokal yang merupakan jatidiri masyarakat Sunda. Kearifan lokal ini kemudian menjadi landasan dalam praktek etnopedagogik. Menurut Alwasilah (dalam Sudaryat, 2015, hlm. 124) etnopedagogik adalah praktek pendidikan berbasis kearifan lokal dalam berbagai ranah seperti pengobatan, seni bela diri, lingkungan hidup, pertanian, ekonomi, pemerintahan, sistem penanggalan dan sebagainya.

Etnopedagogik memandang pengetahuan atau kearifan lokal sebagai sumber inovasi dan keterampilan yang dapat diberdayakan demi kesejahteraan masyarakat. Etnopedagogik kesundaan berorientasi kepada keunggulan manusia secara paripurna. Menurut Warnaen (masih dalam Sudaryat, 2015, hlm. 125-126) manusia paripurna mengacu kepada moral kemanusiaan (MM) yang menjadi pandangan hidup masyarakat Sunda, yakni: 1) Moral manusia terhadap Tuhan (MMT); 2) Moral 
manusia terhadap pribadi (MMP); 3) Moral manusia terhadap manusia lainnya (MML); 4) Moral manusia terhadap alam (MMA); 5) Moral manusia terhadap waktu (MMW); dan 6) Moral manusia dalam mengejar kepuasan lahiriah dan batiniah (MMLB).

Novel yang akan diteliti unsur struktur dan etnopedagogiknya yaitu novel yang berjudul Rasiah Kodeu Biner. Novel ini karangan Dadan Sutisna yang diterbitkan oleh PT Kiblat Buku Utama pada taun 2010. Dari beberapa pertimbangan novel ini dijadikan bahan penelitian karena memiliki isi yang sesuai untuk anak-anak, serta mengandung banyak nilai kemanusiaan yang bisa diteladani oleh anak-anak. Adapun tujuan dari penelitian ini yaitu: 1) untuk mendeskripsikan struktur cerita novel seperti tema, fakta cerita, dan sarana cerita; 2) untuk mendeskripsikan unsur etnopedagogik (moral kemanusiaan) yang terdapat dalam novel; serta 3) menerapkan hasil penelitian sebagai bahan pengajaran apresiasi sastra di SMP.

\section{METODE}

Metode yang digunakan dalam penelitian ini adalah metode deskriptif analisis. Metode ini digunakan untuk menjelaskan secara sistematis, faktual, dan akurat tentang fakta-fakta yang terdapat dalam novel. Adapun fakta tersebut di antaranya unsur struktural dan etnopedagogik moral kemanusiaan yang terdapat dalam novel. Untuk mengetahui data struktur dan etnopedagogik, peneliti menggunakan dua pendekatan yaitu strukturalisme dan etnopedagogik.

Teknik penelitian yang digunakan untuk mengetahui data struktur dan etnopedagogik dalam novel di antaranya: telaah pustaka, teknik analisis data, dan teknik interpretasi. Instrumen penelitian yaitu alat yang digunakan oleh peneliti dalam mengumpulkan data (Arikunto, 2010, kc. 150). Instrumen yang digunakan dalam penelitian ini adalah kartu data, fungsinya untuk mengumpulkan data, mengelompokan data yang terdapat dalam teks sastra, serta memindahkan data yang telah tersedia.

\section{HASIL PENELITIAN DAN PEMBAHASAN}

Novel anak karangan (Sutisna, 2010) yang berjudul Rasiah Kodeu Biner termasuk ke dalam novel misteri, yaitu jenis novel yang menceritakan tentang sebuah rahasia yang kemudian terbukti di akhir cerita. Sesuai dengan jenisnya, tema novel ini adalah tentang rahasia yang terkandung di dalam surat yang ditulis menggunakan angka satu dan nol (bilangan biner). Novel ini menceritakan usaha dari geng opat sadulur yaitu: Rina, Diran, Anis, dan Emod memecahkan isi surat dan menyelamatkan surat agar tidak jatuh ke tangan orang yang tidak memiliki hak atas surat tersebut.

Alur yang digunakan dalam novel yaitu alur campuran. Pengarang dalam menyampaikan cerita tidak menggunakan pembukaan, deskripsi, atau basa-basi, tetapi pengarang secara langsung mengajak pembaca untuk mengetahui jalan cerita. Pada tahap situation pembaca secara langsung dibawa ketengah-tengah cerita ke dalam percakapan para tokoh. Adapun yang sedang berbincang di awal cerita yaitu Rina dan Diran. Isi dari percakapannya, Diran mengajak Rina untuk mengartikan isi dari sebuah surat. Pada tahap generating circumstances, Diran menyimpan surat yang dia temukan di gudang rumahnya, pada waktu yang hampir bersamaan ada orang yang datang ke rumahnya mencari surat tersebut. Pada tahap rising action, Emod diculik oleh orang yang mencari surat. Pada tahap climax mulai terungkap siapa yang telah menulis surat, dan siapa saja yang terlibat atau memiliki hubungan dengan surat tersebut. Tahap ini ditandai dengan Anis yang menyamar sebagai pegawai salon 
toilet. Anis datang ke rumah $\mathrm{Bu}$ Ening untuk mencari informasi mengenai tokoh Sudira (saksi kunci dari surat). Pada tahap denoument, isi surat telah diketahui. Surat tersebut milik $\mathrm{Pa}$ Sukaya seorang pengusaha kaya yang telah meninggal dunia. Pada tahap ini segala urusan telah selesai. Harta Pak Sukaya telah ditemukan, wasiat Pak Sukaya telah dilaksanakan. Di akhir cerita opat sadulur mendapat hadiah beasiswa dari yayasan Pak Sukaya karena dianggap berjasa telah berhasil memecahkan isi surat dan menyelamatkan surat dari orang-orang serakah yang ingin menguasai harta Pak Sukaya.

Dilihat dari kedudukan dan pentingnya peran tokoh dalam suatu cerita, ada dua jenis tokoh yaitu tokoh utama dan tokoh penambah. Walaupun hanya sebuah cerita fiksi, semua tokoh yang ada di dalam novel hidup sebagaimana manusia yang hidup di dunia nyata. Mereka memiliki keinginan dan juga karakter (sipat) tertentu. Oleh karena itu, dalam sebuah novel terdapat tokoh yang memiliki sipat baik (protagonis) dan ada pula tokoh yang memiliki sipat jahat (antagonis). Dalam novel Rasiah Kodeu Biner gambaran fisik dan karakter para tokoh digambarkan secara tidak langsung, artinya pengarang menggunakan tehnik dramatik. Sipat dan sikap paratokoh terlihat dari percakapan tokoh itu sendiri, dari sikapnya dalam menghadapi masalah, dari percakapan tokoh lain, dari sikapnya terhadap tokoh lain, dan dari prilaku sehari-harinya yang tergambar di dalam novel. Jumlah tokoh dalam novel Rasiah Kodeu Biner yaitu 43 orang, tujuh orang termasuk ke dalam tokoh utama, sedangkan sisanya 36 orang termasuk ke dalam tokoh tambahan yang muncul secara situasional untuk mendukung jalannya cerita. Adapun yang menjadi pelaku utama di antaranya: Rina, Diran, Anis, Emod, Bu Ening, Mang Sudira, dan Pak Sukaya.

Rina adalah tokoh yang berhasil mengartikan isi surat. Tokoh Rina termasuk ke dalam tokoh yang memiliki watak statis karena dari awal sampai akhir cerita tokoh ini memiliki watak yang tidak berubah. Sepanjang jalan cerita tokoh Rina digambarkan sebagai anak yang memiliki watak baik. Watak baik Rina di antaranya: rajin belajar, pintar, berpengetahuan luas, memiliki banyak prestasi, memiliki sikap kepemingpinan, cerdas, dan kritis dalam menganalisis masalah yang sedang dihadapinya.

Tokoh Diran memiliki peran yang sangat penting. Dirinyalah yang menemukan surat dalam bilangan biner. Surat ini menjadi latar belakang dari jalannya cerita. Rasa penasaran Diran terhadap isi surat membawa opat sadulur ke dalam petulangan untuk menyelamatkan surat dari orang yang tidak memiliki hak atas surat tersebut. Sama seperti tokoh Rina, tokoh Diran juga termasuk ke dalam tokoh statis, watak Diran digambarkan sebagai anak baik yang memiliki rasa penasaran yang tinggi, serta anak yang paling bersemangat dalam usaha memecahkan rahasia dibalik surat.

Tokoh Emod digambarkan sebagai tokoh yang mimiliki sipat polos, jujur, banyak akal, dan tetap mensyukuri hidup. Tokoh Emod mimiliki peran yang sangat penting dalam cerita. Walaupun tidak digambarkan sebagai anak yang pandai secara akademik seperti Rina, tapi tokoh Emod tidak kalah cerdik. Tokoh ini berhasil membuat strategi dalam upaya menyelamatkan surat ketika dirinya diculik oleh orang yang mencari surat tersebut.

Tokoh Anis juga termasuk ke dalam tokoh statis. Meskipun tokoh ini memiliki sipat yang kurang baik yaitu pemarah dan cuek, namun sipatnya tidak bertolak belakang dengan tokoh protagonis lainnya. Tokoh Anis ikut serta dalam misi memecahkan rahasia surat. Tokoh ini memiliki peran penting dalam upaya pembebasan Mang Sudira dari rumah $\mathrm{Bu}$ Ening. Sejak saat itu, rahasia yang ada di dalam surat mulai terungkap. 
$\mathrm{Bu}$ Ening adalah istri kedua almarhum Pak Sukaya. Watak Bu Ening digambarkan sebagai tokoh antagonis. Tokoh ini digambarkan mimiliki sipat jahat tidak berperasaan, serta serakah karena ingin menguasai harta yang ditinggalkan oleh almarhum suaminya. Tokoh $\mathrm{Bu}$ Ening termasuk tokoh statis, dari awal sampai akhir cerita tokoh ini digambarkan sebagai wanita yang memiliki sipat jahat yang tidak pantas untuk ditiru.

Mang Sudira adalah tangan kanan Pak Sukaya. Tokoh ini banyak diceritakan di akhir cerita. Meskipun demikian, tokoh ini memiliki peran yang sangat penting. Tokoh inilah yang mengetahui seluk beluk surat tersebut. Di akhir cerita diketahui bahwa dirinyalah yang menulis surat dalam bilangan biner sesuai dengan perintah majikannya. Dalam novel ini Mang Sudira digambarkan sebagai tokoh yang memiliki sipat baik seperti amanah, setia, dan tidak terlena oleh harta.

Pak Sukaya adalah majikan dari Mang Sudira, dialah yang memerintahkan Mang Sudira menulis surat menggunakan bilangan biner. Dalam novel ini Pak Sukaya adalah satu-satunya tokoh yang termasuk ke dalam tokoh dinamis, hal itu dikarenakan tokoh Pak Sukaya memiliki watak yang berubah-rubah. Di awal cerita tokoh ini digambarkan sebagai tokoh yang kurang baik karena terlalu sibuk bekerja sehingga melupakan keluwarganya. Namun di akhir cerita wataknya berubah menjadi orang yang bijaksana dan dermawan.

Selain dari tokoh utama, ada juga tokoh tambahan. Tokoh tambahan dalam novel Rasiah Kodeu Biner berjumlah 35 orang, yaitu: Ibu Rina, Ceu Rumsih, Ibu Anis, Bu Lilis, Pak Kodir, Abdul, Bi Darsih, Bapak Emod, Bapak Anis, Bapak Diran, Mang Ujang, Satpam SMP 1001, Fajar, Tetangga Emod, Ahmid, Teman Ahmid, Jang Wandi, Perempuan penjaga warnet, Tetangga Diran, Bi Erum, Ceu
Onéng, Pak Sodik, Kang Adang, Mang Udung, Bi Mimin, Neng Elda, Pak Dahlan, Pak Karjo, Mang Ija, Istri pertama $\mathrm{Pa}$ Sukaya, Anak Pak Sukaya, Dokter Pak Sukaya, Kakek Pak Sukaya, Orang tua Pak Sukaya, dan Kakak Pak Sukaya.

Dalam sebuah cerita fiksi yang menghadirkan tokoh dan alur cerita, perlu ada kejelasan: 1) tempat yang menunjukan di mana berlangsungnya kejadian; 2) waktu yang menunjukan kapan berlangsungnya kejadian; serta 3) latar belakang kehidupan sosial budaya masyarakat tempat para tokoh bergaul dengan sesamanya. Dengan adanya kejelasan tempat, waktu, dan sosial budaya, cerita yang disajikan tentu akan terasa lebih realistik, serta bisa dipahami oleh pembaca khususnya anak-anak. Oleh karena itu, dalam novel anak deskripsi latar harus diceritakan secara lebih rinci. Latar atau setting adalah tempat, waktu, dan suasana berlangsungnya cerita. Kejelasan latar sangat penting agar anak dapat memahami alur cerita, serta dapat membantu mengembangkan imajinasinya. Ada tiga jenis latar yang ditemukan dalam novel ini, di antaranya: latar tempat, latar waktu, dan latar sosial.

Latar tempat mengacu pada pengertian tempat yang menunjukan di mana berlangsungnya kejadian atau cerita. Latar tempat dalam sebuah cerita bisa terjadi di mana saja, misalnya: di rumah, di sekolah, di sebuah gedung, di kelas, di halaman rumah, di jalan raya, atau di jalan sempit yang becek daerah kumuh. Adapun latar tempat yang ditemukan dalam novel ini di antaranya: di rumah Rina, di rumah Diran, di sekolah, di rumah Emod, di rumah $\mathrm{Bu}$ Ening, di kebun binatang, di jalan, di Gang Husin, di Jalan Basajan, di warnet, di Garut, di Tasikmalaya, di rumah sakit, dan di rental komputer.

Latar waktu bisa diartikan sebagai waktu yang menunjukan kapan berlangsungnya kejadian cerita. Latar waktu yang terdapat di dalam novel Rasiah Kodeu 
Biner di antaranya: jam sembilan malam, jam sepuluh malam, jam dua belas malam, jam setengah enam pagi, besok, pagi-pagi, petang, tengah hari, Saptu, kemarin, pulang sekolah, setelah solat subuh, setelah magrib, suatu malam, dan semalam suntuk.

Latar sosial erat hubungannya dengan kehidupan sosial-budaya masyarakat yang digambarkan dalam cerita. Latar sosial novel Rasiah Kodeu Biner berlangsung dalam kehidupan yang sudah modern. Hal ini ditandai dengan kehidupan sosial-budaya masyarakat yang telah menggunakan listrik, alat komunikasi, serta jaringan internet. Disamping itu, dalam novel ini ditemukan ada tiga golongan status sosial, di antaranya: golongan kelas atas (orang kaya), golongan kelas menengah, dan golongan kelas bawah (orang yang tidak mampu). Golongan kelas atas diwakili oleh tokoh Diran dan Pak Sukaya. Beberapa hal yang menunjukan status sosial Diran yaitu: 1) tanggapan dari tokoh lain yang menyebutkan bahwa orang tua Diran adalah orang kaya yang memiliki banyak uang; 2) deskripsi rumah Diran yang digambarkan sangat besar dan juga dilengkapi oleh berbagai fasilitas yang menunjang kehidupannya; 3) memiliki seorang pembantu rumah tangga yang bernama Bi Darsih; 4) dari cara dirinya menggunakan panggilan "Ibu" kepada ibu kandungnya. Tokoh yang termasuk ke dalam kelas atas lainnya yaitu Pak Sukaya. Dia adalah seorang pengusaha sukses yang memiliki pom bensin, pabrik tekstil, dan juga pabrik makanan. Aset Pak Sukaya seperti tanah, saham, dan uang simpanannya di beberapa bank jumlahnya lebih dari satu triliyun. Golongan kelas menengah diwakili oleh Anis yang memiliki orang tua yang bekerja sebagia Pegawai Negeri. Kehidupan golongan menengah tidak banyak diceritakan di dalam novel. Sedangkan golongan kelas bawah diwakili oleh tokoh Emod. Beberapa hal yang menunjukan Emod sebagai orang yang tidak mampu yaitu: 1) ibu Emod adalah seorang penjual pisang di pasar, sedangkan ayahnya adalah seorang penambal ban; 2) rumah Emod terletak di gang sempit, tepatnya di samping tempat pembuangan sampah; 3) rumah Emod digambarkan berukuran kecil dan di dalamnya hanya terdapat kursi yang telah rusak; 4) berbeda dengan cara Diran memanggil ibu kandungnya dengan sebutan "ibu", Emod memanggil ibu kandungnya dengan sebutan "ema".

Sarana cerita dalam novel Rasiah Kodeu Biner di antarnya judul, sudut pandang, gaya bahasa, dan nada (suasana). Judul yang digunakan oleh pengarang adalah Rasiah Kodeu Biner, apabila dilihat dari pilihan diksinya, rasiah berarti hal-hal yang tidak perlu diketahui oleh orang lain. Sedangkan kodeu biner adalah sistem bilangan yang dibangun oleh angka satu dan nol. Secara sederhana berdasarkan judulnya bisa disebutkan novel ini menceritakan sebuah rahasia yang berada di balik angka satu dan nol. Oleh karena itu bisa disebutkan judul novel ini telah mewakili isi cerita secara keseluruhan, yaitu tentang usaha sekelompok anak menguak rahasia dalam surat yang ditulis menggunakan bilangan biner.

Sudut pandang yang digunakan oleh pengarang adalah sudut pandang orang ketiga. Pengarang menempatkan dirinya sebagai orang yang berada di luar cerita. Hal ini ditandai dengan pelaku utama yang secara terus-menerus dari awal sampai akhir cerita disebutkan namanya oleh pengarang.

Gaya bahasa yang digunakan oleh pengarang dalam menyampaikan cerita adalah bahasa sehari-hari yang mudah dipahami oleh anak-anak. Bahasa yang digunakan dalam novel cukup komunikatif, pengarang lebih banyak menggunakan percakapan daripada cerita narasi. Percakapan menggunakan bahasa Sunda loma yang telah disesuaikan dengan tatakrama berbahasa Sunda, artinya bahasa yang digunakan bisa berubah mengguna- 
kan bahasa Sunda ragam hormat ketika tokoh anak-anak sedang berbicara dengan orang tua.

Nada atau suasana yang tergambar dalam novel Rasiah Kodeu Biner yaitu suasana lingkungan yang menjadi latar tempat jalannya cerita, serta keadaan batin para tokohnya. Suasana lingkungan yang tergambar di antaranya: suasana jalan raya ketika pagi hari, suasana di loteng rumah Diran, suasana jaman yang serba modern, suasana di gang sempit, suasana di tempat kumuh, suasana petang, suasana humor, dan suasana ketika sedang bertengkar. Sedangkan suasana batin para tokoh di antaranya: penasaran, malas, menyesal, kesal, serius, bingung, marah, yakin, heran, takut, khawatir, geer, minder, malu, curiga, tidak percaya, dan juga sedih.

Hasil analisis etnopedagogik novel Rasiah Kodeu Biner ditemukan 46 sikap tokoh yang menunjukan moral kemanusiaan. Berdasarkan interprtasi peneliti yang didasari oleh teori Warnaen dari 46 sikap, 11 sikap menunjukan moral manusia (Sudaryat, 2015) terhadap Tuhan (MMT), 32 sikap menunjukan moral manusia terhadap pribadi (MMP), 12 sikap menunjukan moral manusia terhadap manusia lain (MML), satu sikap menunjukan moral manusia terhadap alam (MMA), satu sikap menunjukan moral manusia terhadap waktu (MMW), dan 12 sikap menunjukan moral manusia dalam mengejar kepuasan lahiriah dan batiniah (MMLB).

Moral manusia terhadap Tuhan (MMT) menunjukan sikap dan tindakan manusia yang taat terhadap perintah agama, serta melaksanakan ajaran agamanya. Moral ini didasari oleh keimanan dan ketakwaan terhadap Tuhan, serta kenyataan bahwa manusia lemah dan mudah putus asa. Sikap yang menunjukan moral manusia terhada Tuhan yang terdapat dalam novel di antaranya: 1) melaksanakan solat, sebagai bukti dari ketaatan manusia terhadap kewajiban melaksanakan perintah agama; 2) mengucapkan salam, yaitu salah satu wujud dari melaksanakan ajaran agama; 3) menggunakan tatakrama berbahasa, yaitu wujud dari menghargai bahasa sebagai ciptaan Tuhan Yang Mmaha Esa; 4) memahami adab bergaul antara perempuan dan laki-laki, sebagai gambaran dari akhlak mulia yang diajarkan oleh agama; 5) hidup sederhana, wujud dari melaksanakan ajaran agama karena pada dasarnya Tuhan tidak menyukai orang-orang yang hidup secara berlebihan; 6) jujur, yaitu wujud dari melaksanakan perintah dan ajaran agama; 7) amanah, yaitu wujud dari melaksanakan perintah dan ajaran agama sesuai dengan yang dicontohkan oleh Nabi Muhammad SAW; 8) adil dalam membagi harta, wujud dari melaksanakan perintah dan ajaran agama sesuai dengan aturan pemberian hak waris; 9) berbakti terhadap orang tua, yaitu wujud dari melaksanakan perintah agama; 10) bersyukur dalam hidup, wujud dari sikap menyadari bahwa pada dasarnya sebagai mahluk ciptaan Tuhan manusia itu lemah, tiada daya dan upaya, kecuali hanya bisa bersyukur atas apa yang diberikan oleh Tuhan; dan 11) pasrah, yaitu wujud dari keyakinan terhadap kekuasaan Tuhan Yang Maha Esa.

Moral manusia terhadap pribadi (MMP), yaitu sikap manusia yang berhubungan dengan diri pribadi sebagai makhluk individu yang ditandai oleh kualitas Sumber Daya Manusia (SDM). Sikap yang menunjukan kualitas yang dimiliki oleh diri pribadi dalam novel ini di antaranya: 1) cerdas dalam menganalisis persoalan, merupakan bukti dari manusia yang berpengetahuan luas; 2) terampil menggunakan internet, ciri manusia yang mampu menguasai IPTEK dan dapat menyesuaikan diri dengan perkembangan jaman; 3) banyak akal atau cerdik, ciri dari manusia yang terampil dalam menyelesaikan masalah; 4) menggunakan tatakrama berbahasa, ciri dari manusia yang terdidik; 5) memahami adab bergaul antara perempuan dan laki-laki, ciri dari manusia 
yang memiliki harga diri; 6) juara dalam suatu perlombaan, ciri dari manusia yang bekerja dengan baik; 7) juara kelas, ciri dari manusia yang berilmu; 8) rajin belajar, ciri dari manusia proaktif; 9) rajin bekerja, ciri dari manusia proaktif; 10) sopan ketika sedang bertamu; 11) sederhana; 12) jujur; 13) berani; 14) amanah; 15) siaga; 16) mampu menjaga emosi, 17) adil; 18) baik hati; 19) ramah kepada tamu; 20) memiliki rasa penasaran yang tinggi; 21) hideng atau waras; 22) berbakti kepada orang tua; 23) loyal; 24) tidak pamrih; 25) tanggung jawab; 26) bijaksana; 27) berfikir matang sebelum bertindak; 28) proaktif; 29) pintar (lebih cepat mengerti suatu hal dibandingkan dengan orang lain); 30) berpengetahuan luas; 31) optimis; serta 32) memiliki sikap kepemingpinan.

Moral manusia terhadap manusia lain (MML), yaitu sikap manusia terhadap sesama sebagai makhluk sosial. Sikap yang menunjukan moral terhadap manusia lain yang tergambar dalam novel di antaranya: 1) mengucapkan salam ketika bertamu, sebagai wujud dari menghargai tuan rumah; 2) menggunakan tatakrama berbahasa, sebagai wujud dari menghargai orang yang diajak berbicara; 3) memahami adab bergaul antara perempuan dan lakilaki, wujud dari kesopanan dalam hidup bermasyarakat; 4) sopan ketika bertamu, wujud dari menghormati tuan rumah; 5) saling menolong; 6) bermusyawarah; 7) bekerja sama; 8) tenggang rasa; 9) ramah terhadap tamu (soméah hadé ka sémah); 10) menghargai orang tua; 11) setia kepada pemingpin (atasan); serta 12) tidak pambrih, wujud dari rasa ikhlas menolong sesama.

Moral manusia terhadap alam (MMA), yaitu sikap dan tindakan manusia dalam menjaga alam, menghindarinya dari kerusakan, serta memperbaiki alam yang telah rusak. Sikap yang menunjukan moral manusia terhadap alam yang tergambar dalam novel ini ditunjukan oleh sikap 1) hobi bercocok tanam.
Moral manusia terhadap waktu (MMW), yaitu sikap dan tindakan manusia dalam memanfaatkan waktu. Sikap yang menunjukan moral manusia terhadap waktu yang tergambar dalam novel ini ditunjukan oleh sikap 1) disiplin terhadap waktu, tidak terlambat, tapi sesuai dengan waktu yang telah ditentukan.

Moral manusia dalam mengejar kepuasan lahiriah dan batiniah (MMLB), yaitu sikap dan tindakan manusia dalam memenuhi kebutuhan lahir dan batin. Moral ini ditandai dengan adanya kesadaran terhadap etika dan estetika. Sikap yang menunjukan moral manusia dalam mengejar kepuasan lahiriah dan batiniah yang tergambar dalam novel ini di antaranya: 1) melaksanakan solat, didasari oleh keimanan dapat menimbulkan kepuasan batin karena telah melaksanakan perintah Tuhan; 2) memahami adab bergaul antara perempuan dan laki-laki, wujud dari kesadaran hidup bermasayarakat, dapat menimbulkan kepuasan lahir dan batin karena perilaku tersebut telah sesuai dengan aturan yang ditetapkan oleh masyarakat; 3) juara kelas, dapat menimbulkan kepuasan batin karena merasa diri lebih unggul dari orang lain; 4) juara lomba, dapat menimbulkan kepuasan batin karena merasa diri lebih unggul dari orang lain; 5) memperhatikan penampilan, wujud dari kesadaran estetika, dapat menimbulkan kepuasan ketika seseorang menerima pujian dari orang lain karena telah berpakaian dengan memperhatikan nilai keindahan; 6) gemar membaca, dapat menimbulkan kepuasan karena membaca dapat memberi hiburan serta menambah pengetahuan; 7) sehat jasmani, menimbulkan kepuasaan dapat melaksanakan berbagai aktivitas karena jiwa dan raga terhindar dari berbagai penyakit; 8) berbakti kepada orang tua, menimbulkan kepuasan karena merasa diri bermanfaat; 9) pintar, lebih cepat mengerti suatu hal dibandingkan dengan orang lain, menimbulkan kepuasan karena merasa diri 
memiliki banyak kemampuan; 10) berpengetahuan luas, menimbulkan kepuasan karena merasa diri mengetahui banyak hal; 11) rajin bekerja mencari rejeki dapat menimbulkan kepuasan ketika semua kebutuhan hidup telah terpenuhi; 12) memiliki sikap kepemingpinan dapat menimbulkan kepuasan karena telah mampu mempengaruhi dan mengatur orang lain.

Novel anak Rasiah Kodeu Biner bisa dijadikan salah satu alternatif bahan pengajaran apresiasi sastra di SMP karena telah memenuhi beberapa kriteria dalam pemilihan bahan ajar, di antaranya: 1) relevan dengan standar kompetansi dan kompetensi dasar yang ingin dicapai, sesuai dengan nomor 9.2 mampuh ngungkapkeun pikiran, rarasaan, jeung kahayang sacara lisan dina wangun kritik, pidato, sawala, drama, nyaritakeun novél, jeung musikalisasi puisi, poin 9.2.3 nyaritakeun eusi novél; 2) bisa didapatkan dengan mudah karena novel Rasiah Kodeu Biner bahan pengajaran yang jelas sumbernya, novel ini karangan Dadan Sutisna dan diterbitkan oleh PT Kiblat Buku Utama pada tahun 2010; 3) praktis, setelah membaca novel ini siswa dapat merasakan hasil dari karya sastra, mendapat pengalaman dan hiburan dari membaca karya sastra, serta dapat menyusun karya sastra dengan cara menceritakan kembali isi novel dengan menggunakan bahasa sendiri; 4) bermanfaat bagi siswa, novel ini memiliki struktur yang jelas seperti tema, fakta cerita, dan sarana cerita sehingga teori sastra mudah dipahami oleh siswa SMP, selain itu novel ini memiliki banyak nilai moral kemanusiaan yang dapat diteladani oleh siswa, sangat cocok dengan karakteristik dan kepribadian siswa di sekolah; 5) dilihat dari aspek linguistik, novel ini telah sesuai dengan kemampuan pemahaman berbahasa siswa SMP karena pengarang menggunakan bahasa seharihari yang mudah dipahami oleh siswa, serta dapat mendidik siswa menggunakan tatakrama bahasa Sunda.

\section{SIMPULAN}

Berdasarkan pembahasan hasil penelitian, dapat disimpulkan sebagai berikut: (1) Novel anak Rasiah Kodeu Biner karangan Dadan Sutisna memiliki struktur yang jelas seperti tema, fakta cerita (galur, palaku, dan latar), dan sarana cerita (judul, sudut pandang, gaya bahasa, dan nada atau suasana); (2) Novel anak Rasiah Kodeu Biner karangan Dadan Sutisna memiliki banyak nilai etnopedagogik moral kemanusiaan; dan (3) Novel anak Rasiah Kodeu Biner karangan Dadan Sutisna dapat dijadikan alternatif bahan pengajaran karena telah memenuhi beberapa kriteria dalam pemilihan bahan ajar.

\section{DAFTAR RUJUKAN}

Arikunto, S. (2010). Prosedur Penelitian. Jakarta: Rineka Cipta.

Kurniawan, H. (2009). Sastra Anak. Yogyakarta: Graha Ilmu.

Nurgiyantoro, B. (2010). Sastra Anak; Pengantar Pemahaman Dunia Anak. Yogyakarta: Gadjah Mada University Press.

Sudaryat spk. (2007). Makaya Basa. Bandung: Sonagar Préss.

----------. (2015). Wawasan Kesundaan. Bandung: Jurusan Pendidikan Bahasa Daerah FPBS Universitas Pendidikan Indonesia.

Sutisna, D. (2010). Rasiah Kodeu Binér. Bandung: PT Kiblat Buku Utama.

\section{UCAPAN TERIMA KASIH}

Ucapan terima kasih penulis sampaikan kepada semua pihak yang telah membantu dalam menyelesaikan penelitian ini. Kepada penyunting Jurnal Lokabasa, penulis mengucapkan terima kasih atas dimuatnya tulisan ini. 